\title{
Arsenic accumulation by rice grown in soil treated with roxarsone
}

\author{
Chen-Wuing Liu1*, Ching-Chieh Lin'1, Cheng-Shin Jang², Guey-Rong Sheu³, and Lo Tsui4 \\ 1 Department of Bioenvironmental Systems Engineering, National Taiwan University, Taipei, Taiwan, 10617, ROC \\ 2 Department of Leisure and Recreation Management, Kainan University, Luzhu, Taoyuan, Taiwan, 33857, ROC \\ 3 Department of Atmospheric Sciences and Institute of Atmospheric Physics, National Central University, Jhongli, Taoyuan, Taiwan, \\ 32001, ROC \\ 4 Department Safety Health and Environmental Engineering, Mingchi University of Technology, Taishan, Taipei, Taiwan, 24301, ROC
}

\begin{abstract}
Poultry litter is widely used as a fertilizer for lowland rice in Taiwan and China. However, the organic-arsenic compound roxarsone (additive of poultry feed) in poultry litter can be absorbed by the plants and the resulting arsenic (As) contamination may pose a serious threat to human health. This study used various amounts of poultry litter contaminated with roxarsone in pot experiments to evaluate the effect of roxarsone on rice agronomic parameters and the bioaccumulation of total and inorganic As in rice-plant tissues. Rice-grain yield decreased significantly with increasing As content of the soil, and the critical threshold that killed rice was 200 mg roxarsone (kg soil) ${ }^{-1}$. The As concentrations in root, straw, leaf, husk, and grain increased with increasing soil As $(p<1 \%)$. At $100 \mathrm{mg}$ roxarsone per $\mathrm{kg}$ of soil, the As concentration in the rice grain exceeded the statutory permissible limit of $1.0 \mathrm{mg} \mathrm{As} \mathrm{(kg} \mathrm{dry} \mathrm{weight)}{ }^{-1}$ and at $25 \mathrm{mg}$ roxarsone (kg soil)-1, the inorganic As concentrations in grains exceeded the statutory limit of $0.15 \mathrm{mg}$ of inorganic As kg-1 in China. For all treatments, the As concentrations in various plant tissues at maturity follow the order: root $>$ stem $>$ leaf $>$ husk $>$ grain. Arsenite was the predominant species in root, straw, and grain, while arsenate was the predominant species in leaf and husk. No significant difference existed between the amounts of arsenite and arsenate when various amounts of poultry litter were applied. This result illustrates that large amounts of added roxarsone are not only toxic to rice but also accumulate in grains in the inorganic As forms, potentially posing a threat to human health via the food chain.
\end{abstract}

Key words: arsenate / arsenite / Oryza sativa L. / poultry manure / Taiwan

Accepted February 13, 2009

\section{Introduction}

Roxarsone (3-nitro-4-hydroxyphenylarsonic acid) is an organic-arsenic compound, which has been used over several decades as an additive to poultry feed, not only to control coccidial intestinal parasites but also to improve feed efficiency and to increase growth. Mellon et al. (2001) indicated that roxarsone is frequently added to poultry feed in concentrations of 23-45 $\mathrm{g} \mathrm{t}^{-1}$. While small amounts of roxarsone may be retained in the meat of chicken or pork, most ingested roxarsone is excreted in unchanged form from animal bodies (Moore et al., 1998). Therefore, poultry litter generally contains some levels of arsenic (As) and the total As concentrations in fresh poultry manure can reach up to 27 $\mathrm{mg} \mathrm{kg}^{-1}$ (Hancock et al., 2002). Several studies could show that roxarsone is stable in dry litter (Rutherford et al., 2003) and that $70 \%-75 \%$ of the total As in poultry litter is watersoluble (Jackson and Miller, 1999). Thus, roxarsone can be easily leached during composting (Jackson and Bertsch, 2001) and degradation rates of roxarsone increase with the amount of water added. At high-moisture and high-temperature conditions, most roxarsone is transformed into arsenate after $30 \mathrm{~d}$ of incubation (Brown et al., 2005).
Poultry litter that consists of the manure and bedding material (such as sawdust or wood chips) has a high nutrient content and is used commonly as a fertilizer on cropland and pastures to meet the $\mathrm{N}$ requirements of crops. Excrements are generally disposed of by spreading them onto agricultural fields near the poultry houses (Edwards et al., 1992). Dry poultry manure with roxarsone is applied to corn fields of Virginia in the USA at an annual rate of about $4.5 \mathrm{t} \mathrm{ha}^{-1}$ (Hyer et al., 2001), resulting in gradually increasing concentrations of As in water and soil. Soil samples collected in field sites fertilized with roxarsone-rich poultry litter for many years have higher As concentrations than similar soils without poultry litter amendments (Brown et al., 2005).

Poultry litter is used in organic agriculture, and in the southern provinces of China most arsenic-bearing wastes (roxarsone or arsanilic acid) are applied into paddy fields as a fertilizer (Wang et al., 2006). Wherever poultry litter is used as a fertilizer in paddy fields, this practice is causing As to be released into soil environments with low redox potential (Eh), facilitating its uptake by plants and increasing the risk to human health.

\footnotetext{
* Correspondence: Dr. C.-W. Liu;

e-mail: Icw@gwater.agec.ntu.edu.tw
} 
In the soil of paddy fields, arsenate is readily converted to arsenite because of anaerobic conditions (Abedin et al., 2002c). The uptake of arsenite by rice is higher than that of other As species, and high As concentrations in rice are frequently present in highly As-polluted soil or irrigation water, affecting the safe consumption of rice by humans and animals (Krishnamurti and Naidu, 2002). Different As species have different toxicities to organisms. Typically, inorganic As is more toxic than organic As. Few studies focused on different As species in rice. The aim of this work was to evaluate the effect of roxarsone on rice agronomic parameters and the bioaccumulation of total As and As species in various tissues of rice plants.

\section{Materials and methods}

\subsection{Reagents}

Deionized water (electrical conductivity: $0.056 \mathrm{dS} \mathrm{m}^{-1}$ ) was used for the preparation of reagents and standards. All glassware was soaked in $10 \%$ nitric acid for $24 \mathrm{~h}$, then washed with tap water and rinsed three times with deionized water before use. The stock standard solutions of As, monomethyl-arsonic acid (MMA) and dimethyl-arsinic acid (DMA), were prepared by dissolving commercially available As salts in water: arsenite (sodium arsenite; Chem Service), MMA (monosodium methanearsonate, 97.5\%, $\mathrm{CH}_{4} \mathrm{AsNaO}_{3} \cdot 1.5 \mathrm{H}_{2} \mathrm{O}$; Chem Service), and DMA (dimethylarsenic acid sodium salt, 97\%, $\mathrm{C}_{2} \mathrm{H}_{6} \mathrm{AsNaO}_{2}$. $3 \mathrm{H}_{2} \mathrm{O}$; Merck). The arsenate solution (1000 mg L-1) was obtained from Merck.

\subsection{Soil, plant, and poultry-litter material}

A pot experiment was conducted in a glasshouse of the National Taiwan University for $130 \mathrm{~d}$ from transplanting to the harvest of rice. The temperatures in glasshouse ranged from $21^{\circ} \mathrm{C}$ to $34^{\circ} \mathrm{C}$, and the relative humidity was $60 \%-70 \%$. The soil (depth of $0-15 \mathrm{~cm}$ ) and poultry litter used in this study were collected from central Taiwan rice farms, where about $61 \%$ of paddy rice of Taiwan is produced. Soil and poultry litter were sun-dried for $10 \mathrm{~d}$. Large soil aggregates were broken by crushing with a hammer and passed through a $2 \mathrm{~mm}$ sieve.

Soil $\mathrm{pH}$ was measured using a glass electrode and a 1:1 soilor litter-to-water suspension. Ammonium acetate, adjusted to pH 7.0 (Page et al., 1982), was used as extractant to determine soil exchangeable bases and CEC using the leaching method. The samples were digested (at $120^{\circ} \mathrm{C}$ for $3 \mathrm{~h}$ ) using $\mathrm{HNO}_{3}-\mathrm{H}_{2} \mathrm{O}_{2}$ (Tang and Miler, 1991) to determine total As contents. Available $\mathrm{P}$ was determined colorimetrically using $0.5 \mathrm{~N} \mathrm{NaHCO}_{3}$ as extractant. Total $\mathrm{C}$ and $\mathrm{N}$ were determined using a CNHS element analyzer (Perkin Elmer 2400 USA). Soil particle size was determined using the pipette method. Selected physico-chemical parameters of soil and poultry litter are listed in Tab. 1. The $\mathrm{pH}$ of soil and poultry litter was 6.9 and 9.2, respectively. Total As contents in soil and poultry litter were $6.8 \mathrm{mg} \mathrm{kg}^{-1}$ and $4.7 \mathrm{mg} \mathrm{kg}^{-1}$, respectively. The poultry litter contained $4.23 \% \mathrm{~N}$.
Table 1: Physico-chemical properties of soil and poultry litter. Data represent means \pm SE of three replicates.

\begin{tabular}{lrc}
\hline Parameters & \multicolumn{1}{c}{ Soil } & Poultry litter \\
\hline $\mathrm{pH}$ & $6.9 \pm 0.2$ & $9.2 \pm 0.3$ \\
Moisture (\%) & $19.2 \pm 1.4$ & $12.6 \pm 1.2$ \\
Sand (\%) & $34.4 \pm 2.2$ & \multicolumn{1}{l}{-} \\
Silt (\%) & $57.2 \pm 3.6$ & \multicolumn{1}{l}{-} \\
Clay (\%) & $8.4 \pm 0.1$ & \multicolumn{1}{c}{-} \\
Organic carbon (\%) & $5.1 \pm 0.5$ & $47.6 \pm 2.9$ \\
Total nitrogen (\%) & $0.4 \pm 0.1$ & $4.2 \pm 0.1$ \\
Available phosphorus (\%) & $0.9 \pm 0.1$ & $4.6 \pm 0.9$ \\
Available potassium (\%) & $11.1 \pm 0.2$ & $2.4 \pm 0.2$ \\
Total arsenic (mg kg $\left.{ }^{-1}\right)$ & $6.8 \pm 0.9$ & $4.7 \pm 0.9$ \\
\hline
\end{tabular}

Pots of $25 \mathrm{~cm}$ diameter and $30 \mathrm{~cm}$ height were filled with $3 \mathrm{~kg}$ soil, amended with poultry litter at rates of 4 and $8 \mathrm{t} \mathrm{ha}^{-1}$, and five levels of roxarsone $(0,25,50,100$, and $200 \mathrm{mg}$ roxarsone [kg soil] ${ }^{-1}$ ) were adjusted by addition of 4-hydroxy-3nitrobenzenearsonic acid. Five 30 day-old seedlings of the widely used lowland rice (Oryza sativa L.) cultivar Taiken 8 were transplanted, and the pots were watered daily with tap water to maintain flooded conditions $(3-4 \mathrm{~cm}$ of floodwater). The experiment was arranged in a factorial completely randomized design with three replications (total of 30 pots).

\subsection{Sample collection and preservation}

The $\mathrm{pH}$ and Eh of the soil and the As concentration in the soil solution were analyzed $7,14,21,28$, and $35 \mathrm{~d}$ after rice transplanting. Soil-solution samples were collected from bottom pipes. The water samples were stored in polyethylene containers, cleaned with $10 \%$ nitric acid and then rinsed with deionized water. The water samples were filtered through $0.45 \mu \mathrm{m}$ filters before analyses. The $\mathrm{pH}$ and redox potential (Eh) were directly measured by $\mathrm{pH}$ and Eh probes in the soil, reading data after $10 \mathrm{~min}$.

Rice plant-sample collection and preservation were done according to Abedin et al. (2002b). Rice plants were harvested by cutting at $4 \mathrm{~cm}$ above the soil to avoid basal tissues to be contaminated by the applied roxarsone. Rice spikelets were separated from the panicles by hand, and empty and filled spikelet numbers were recorded. Rice grains were separated from their husks using a mortar and pestle and ground using a stainless-steel grinder (Braun KSM2 Coffer Grinder, Germany). The straw biomass was recorded after oven-drying at $50^{\circ} \mathrm{C}$ for $48 \mathrm{~h}$. After harvest, the soil was oven-dried at $50^{\circ} \mathrm{C}$. Roots were separated from soil during disaggregation and sieving to $<2 \mathrm{~mm}$ rinsed in deionized water and dried at $50^{\circ} \mathrm{C}$ for $48 \mathrm{~h}$. Plant samples (root, straw, leaf, grain, and husk) were ground to pass a $1 \mathrm{~mm}$ sieve, and the dried samples were stored in a desiccator until chemical analysis. 


\subsection{Analysis of arsenic in rice}

Straw, root, leaf, grain (brown rice), husk, and soil samples were analyzed for total As concentrations. Plant material was digested with concentrated $\mathrm{HNO}_{3}$ and $30 \% \mathrm{H}_{2} \mathrm{O}_{2}$ at $120^{\circ} \mathrm{C}$ (Tang and Miller, 1991; Abedin et al., 2002b). Five milliliters of concentrated $\mathrm{HNO}_{3}$ were added to about $200 \mathrm{mg}$ of dry plant material weighed into a $75 \mathrm{~mL}$ digestion tube and allowed to sit overnight. The following day, the digestion tubes were placed on a heating block, and the temperature was raised to $60^{\circ} \mathrm{C}$. Three $1 \mathrm{~mL}$ aliquots of $30 \% \mathrm{H}_{2} \mathrm{O}_{2}$ were added to each tube, and the temperature was gradually raised to $120^{\circ} \mathrm{C}$. The samples were allowed to digest for $3 \mathrm{~h}$, after which the volume was reduced to $3-4 \mathrm{~mL}$. The digests were cooled, diluted to $50 \mathrm{~mL}$ with deionized water, and filtered through Whatman No. 42 filter paper into plastic bottles. All glassware and plastic bottles were first acid-washed in $2 \%$ $\mathrm{HNO}_{3}$, rinsed in deionized water, and dried.

The acid digests of soils, roots, straws, leaf, grain, and husks were analyzed for total arsenic by HG/AAS, an atomicabsorption spectrometer (AAS) (AA100 Perkin-Elmer Shelton, USA) and a hydride generator (HG) (FIAS 400 PerkinElmer Shelton, USA). To reduce the arsenic to arsine, $0.5 \%$ $\mathrm{NaBH}_{4}$ in $0.25 \% \mathrm{NaOH}$ and $1 \mathrm{~N} \mathrm{HCl}$ were added into $200 \mu \mathrm{L}$ of a digested sample. The accuracy of the analysis was checked by the certified standard reference material SRM1568a rice flour from the National Institute of Standards and Technology (NIST). The arsenic concentration in certified reference material was $0.29 \pm 0.03 \mathrm{mg} \mathrm{kg}^{-1}$ while the measured arsenic was $0.28 \pm 0.02 \mathrm{mg} \mathrm{kg}^{-1}$.

\subsection{Analysis of arsenic species}

Trifluoroacetic acid (TFA) extraction of As species from plant material was conducted according to the method described by Abedin et al. (2002b). Portions of $0.25 \mathrm{~g}$ ground plant material were weighed into $100 \mathrm{~mL}$ glass digestion tubes to which $2 \mathrm{~mL}$ of 2 M TFA were added. The digestion tube was then placed on a digestion block and heated at $100^{\circ} \mathrm{C}$ for $6 \mathrm{~h}$. The digest was rotavapored to dryness, and the residue redissolved with deionized water, filtered through $0.22 \mu \mathrm{m}$ filters, and made up to a $25 \mathrm{~mL}$ volume with deionized water. The extracts were stored at $-4^{\circ} \mathrm{C}$ prior to analysis by HPLC-HG-AAS (Huang et al., 2003). A high-performance liquid chromatograph, HPLC (Hitachi 7110, Naka, Japan), equipped with an anion column (Machey-Nagel Nucleosil, $10 \mu \mathrm{m}, 250 \times 4.6 \mathrm{~mm}$ ) and connected to $\mathrm{HG} / \mathrm{AAS}$, was used to separate $\mathrm{As}(\mathrm{III}), \mathrm{As}(\mathrm{V}), \mathrm{DMA}$, and MMA. All glassware and plasticware were first acid-washed in $2 \% \mathrm{HNO}_{3}$, rinsed in deionized water, and dried. The laboratory procedure recovery rates of As (III), As (V), MMA, and DMA were $101.2 \%, 97.6 \%$, and $98.1 \%$, respectively. The coefficient of variation (CV) was always below $5 \%$.

\subsection{Transfer factor}

The transfer factor (TF), relating the concentration of As in basal to that in upper tissue, was used to estimate the propensity of arsenic accumulation in various plant parts:

$T F=\frac{C_{u t}}{C_{b t}}$ where $C_{u t}$ is the As concentration in upper tissue and $C_{b t}$ is the As concentration in basal tissue.

\subsection{Statistical analysis}

One-way analysis of variance (ANOVA) was adopted to examine the statistical differences among various treatments of effective tiller numbers, grain yield, 1000-grain weight, and As concentrations in various plant parts. The SAS package was used for statistical analyses at a $95 \%$ level of probability.

\section{Results}

\subsection{Soil pH, Eh, and As in soil solution}

With $4 \mathrm{t} \mathrm{ha} \mathrm{a}^{-1}$ of added poultry litter, soil $\mathrm{pH}$ ranged from 6.8 to 7.2 and Eh ranged from -231 to $-398 \mathrm{mV}$. With $8 \mathrm{tha}^{-1}$ of poultry litter, soil $\mathrm{pH}$ was 6.8 to 7.1 and Eh was -160 to $-398 \mathrm{mV}$. Figure 1 shows the temporal dynamics of As species in soil solution. Arsenite was the predominant species throughout the experiment due to the flooded and reduced conditions in soil solution. The As speciation over $35 \mathrm{~d}$ indicated that $\mathrm{As}(\mathrm{III}), \mathrm{As}(\mathrm{V}), \mathrm{MMA}$, and DMA made up 56\%, $35 \%, 6 \%$, and $2 \%$, respectively, of the total As with $8 \mathrm{t} \mathrm{ha}^{-1}$ and $63 \%, 31 \%, 4 \%$, and $2 \%$, respectively, with $4 \mathrm{tha}^{-1}$ of added poultry litter.


Time / d

Figure 1: Dynamics of arsenic species in soil solution for flooded-paddy field conditions (i.e., saturation to permanent immersion of the soil up to $3-4 \mathrm{~cm}$ of solution), soil amended with dry poultry litter of (a) $8 \mathrm{t} \mathrm{ha}^{-1}$ and (b) $4 \mathrm{t} \mathrm{ha}^{-1}$. As(III): Arsenite, As(V): Arsenate, DMA: Dimethyl-arsinic acid, MMA: Monomethyl-arsonic acid. 


\subsection{Rice performance and arsenic concentrations}

Rice plants withered after $56 \mathrm{~d}$ in the treatment with $200 \mathrm{mg}$ roxarsone ( $\mathrm{kg} \mathrm{soil})^{-1}$. Yield, tiller numbers, and 1000-grain weight of rice grown in $0,25,50$, and $100 \mathrm{mg}$ roxarsone (kg soil)-1 are presented in Fig. 2 . The amount of poultry litter added did not significantly affect the plant parameters, except for the straw weight in the $25 \mathrm{mg}$ - and $50 \mathrm{mg}$-roxarsone treatments. However, the amount of roxarsone added significantly reduced tiller number, 1000-grain weight, and grain yield $(p<5 \%)$. This As-induced reduction was most pronounced in tiller number and grain yield (Fig. 2).

Table 2 presents the total As concentrations in rice plants. Increasing the amount of roxarsone significantly increased the As concentrations in root, straw, leaf, husk, and grain. Total As concentrations in rice tissues followed in all treatments the order: root $>$ straw $>$ husk $>$ leaf $>$ grain. Adding more roxarsone to the soil resulted in larger differences between plant organs. However, DMA and MMA were not detected in all rice tissues. Inorganic arsenic in rice tissues also followed the same order: root $>$ straw $>$ husk $>$ leaf $>$ grain. The extraction efficiencies ranged from $73.22 \%$ to $97.6 \%$.

Figure 3 shows variations of inorganic As for different treatments. Arsenate and arsenite were present in rice root, straw, and leaf. However, arsenate was not found in grain and arsenite was not found in husk. Arsenite concentrations were higher than arsenate concentrations in root, straw, and grain, while arsenate concentrations were greater in leaf and husk.

Most arsenite and arsenate concentrations did not vary with the amount of poultry litter added (4 or $8 t^{~ h a}{ }^{-1}$ ), except for arsenite in root and straw with $100 \mathrm{mg}$ of roxarsone and arsenate in the leaf with $50 \mathrm{mg}$ roxarsone added. In the 100 $\mathrm{mg}$ roxarsone ( $\mathrm{kg}$ soil) ${ }^{-1}$ treatment, arsenite in straw and arsenate in leaf increased significantly with the amount of poultry litter added. Generally, increasing the amount of roxarsone significantly increased the inorganic-As concentrations in root, straw, leaf, husk, and grain $(p<1 \%$; Tab. 3).

\subsection{Arsenic transfer from soil to shoot and grain}

The ratios of arsenic uptake from soil to root of rice ranged from 1.2 to 4.3 (calculated from Tab. 2). However, As-transfer factors for different plant parts in rice were all less than 1.0 (Fig. 4). Across treatments, the average As transfer from root to straw was 0.25 , indicating that most As accumulated in the root. Moreover, As-transfer factors from straw to leaves,

Table 2: Arsenic concentrations in different plant parts of rice amended with increasing amounts of roxarsone. Data represent means \pm SE of three replicates. Extraction efficiency $(\%)=$ sum of As species (TFA extraction) / total As (nitric acid digestion).

\begin{tabular}{|c|c|c|c|}
\hline $\begin{array}{l}\text { Roxarsone } \\
\text { treatment }\end{array}$ & Total As & $\begin{array}{l}\text { Inorganic } \\
\text { As }\end{array}$ & $\begin{array}{l}\text { extraction } \\
\text { efficiency }\end{array}$ \\
\hline / mg (kg soil) $)^{-1}$ & $/ \mu \mathrm{g} \mathrm{g}^{-1}$ & $/ \mu \mathrm{g} \mathrm{g}^{-1}$ & $1 \%$ \\
\hline & root & & \\
\hline 0 & $8 \pm 0.52$ & $6 \pm 0.37$ & $73 \pm 2$ \\
\hline 25 & $56 \pm 2.57$ & $45 \pm 1.71$ & $79 \pm 1$ \\
\hline 50 & $134 \pm 9.27$ & $103 \pm 12.86$ & $76 \pm 5$ \\
\hline 100 & $\begin{array}{l}395 \pm 12.90 \\
\text { straw }\end{array}$ & $334 \pm 20.70$ & $84 \pm 3$ \\
\hline 0 & $2.35 \pm 0.07$ & $2.02 \pm 0.09$ & $85 \pm 2$ \\
\hline 25 & $17.56 \pm 1.77$ & $13.96 \pm 0.41$ & $80 \pm 6$ \\
\hline 50 & $27.26 \pm 2.13$ & $22.88 \pm 3.30$ & $84 \pm 11$ \\
\hline 100 & $\begin{array}{l}72.57 \pm 6.62 \\
\text { leaf }\end{array}$ & $60.02 \pm 8.99$ & $82 \pm 5$ \\
\hline 0 & $1.21 \pm 0.07$ & $0.93 \pm 0.05$ & $76 \pm 4$ \\
\hline 25 & $14.96 \pm 0.87$ & $14.50 \pm 1.00$ & $97 \pm 12$ \\
\hline 50 & $21.95 \pm 0.33$ & $18.06 \pm 0.54$ & $82 \pm 3$ \\
\hline 100 & $\begin{array}{l}33.29 \pm 1.92 \\
\text { husk }\end{array}$ & $27.32 \pm 1.85$ & $82 \pm 4$ \\
\hline 0 & $0.35 \pm 0.03$ & $0.28 \pm 0.02$ & $79 \pm 2$ \\
\hline 25 & $2.27 \pm 0.33$ & $1.74 \pm 0.36$ & $75 \pm 5$ \\
\hline 50 & $2.80 \pm 0.20$ & $2.05 \pm 0.16$ & $73 \pm 1$ \\
\hline 100 & $\begin{array}{l}3.80 \pm 0.40 \\
\text { grain }\end{array}$ & $3.48 \pm 0.17$ & $92 \pm 6$ \\
\hline 0 & $0.17 \pm 0.01$ & $0.13 \pm 0.01$ & $78 \pm 4$ \\
\hline 25 & $0.31 \pm 0.01$ & $0.23 \pm 0.04$ & $73 \pm 8$ \\
\hline 50 & $0.50 \pm 0.04$ & $0.42 \pm 0.03$ & $84 \pm 4$ \\
\hline 100 & $1.09 \pm 0.05$ & $0.84 \pm 0.04$ & $77 \pm 3$ \\
\hline
\end{tabular}
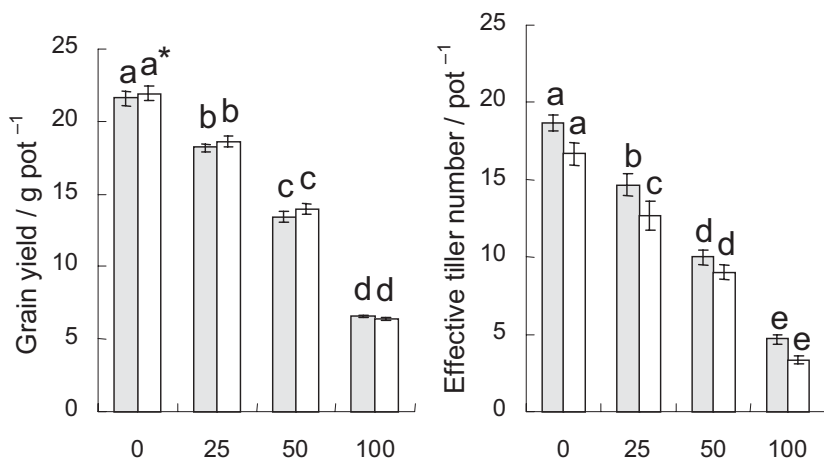

Roxarsone treatment $/ \mathrm{mg} \mathrm{kg}^{-1}$

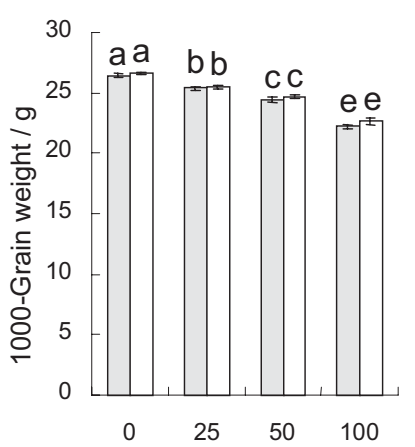

Figure 2: Effect of treating soil with roxarsone on rice-biomass parameters for two amounts of poultry litter added; black: $8 \mathrm{t}$ ha ${ }^{-1}$, white: $4 \mathrm{t}$ ha $^{-1}$. Error bars represent \pm SE from three replications. *Mean \pm SE bars followed by same letters do not differ significantly from each with $p=5 \%$. 

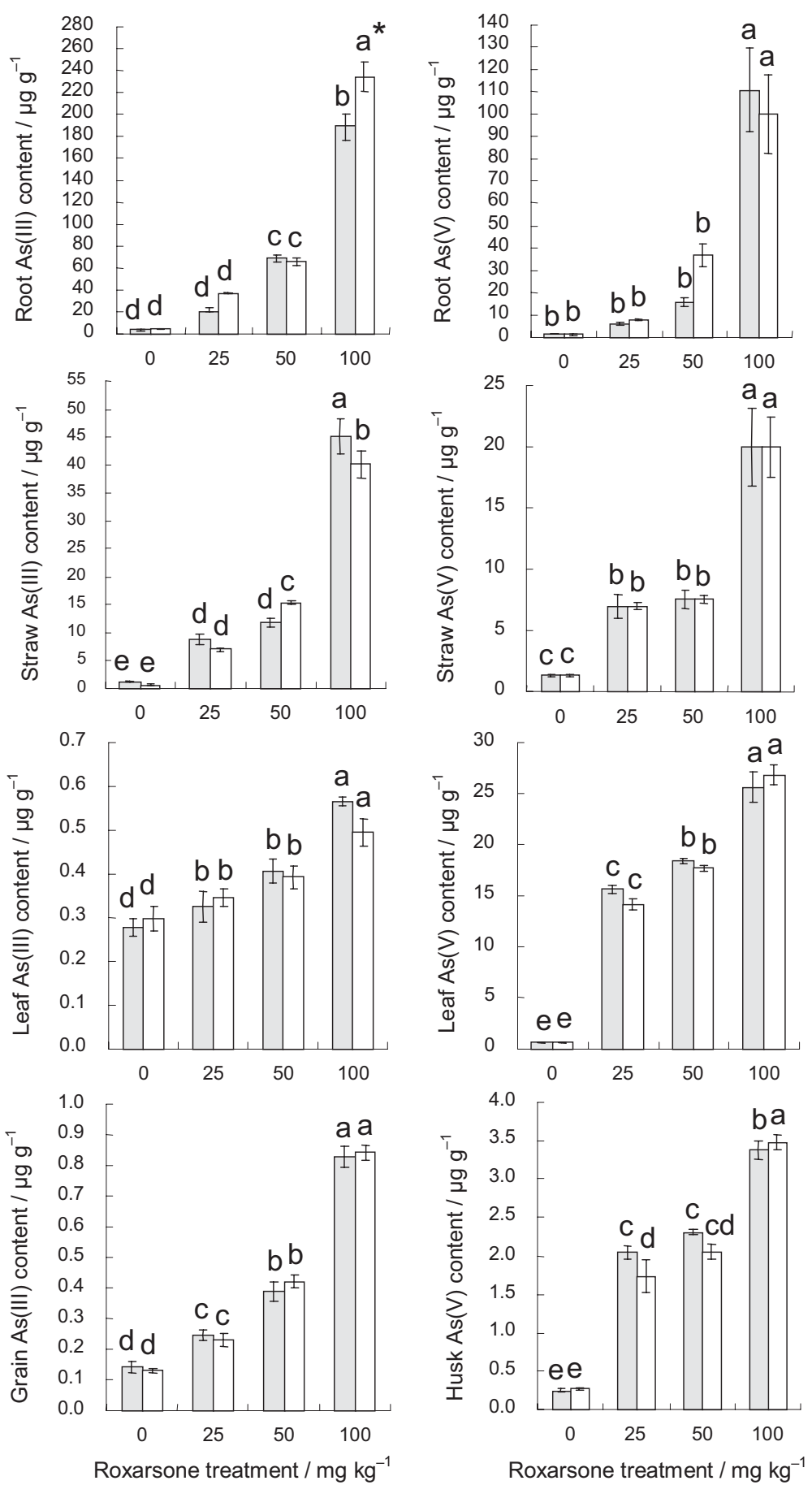

Figure 3: Arsenite and arsenate concentrations in rice plant parts for two amounts of poultry litter added; black: $8 \mathrm{t} \mathrm{ha}^{-1}$, white: $4 \mathrm{t} \mathrm{ha}^{-1}$. Error bars represent \pm SE from three replications. *Means \pm SE bars followed by same Roxarsone treatment / $\mathrm{mg} \mathrm{kg}^{-1}$ letters differ significantly from each other with $p=5 \%$.

husk, and grain were $0.66,0.11$, and 0.03 , respectively, indicating the largest amounts of As being transferred from straw into leaf and only little into grain.

\section{Discussion}

\subsection{Effect of arsenic on rice growth}

The experiment showed that when added in excess of $200 \mathrm{mg} \mathrm{kg}^{-1}$, roxarsone was toxic to paddy rice. Arsenic has been associated with metabolic processes and found to inhibit plant growth, sometimes leading to death (Marin et al., 1993). Our work demonstrated that rice-straw weights decreased significantly $(p<5 \%)$ as the soil As contents increased. Similar findings were reported by Abedin et al. (2002a, b) and by Wang et al. (2006). Exposure to As reportedly also reduced shoot biomass and growth of rice (Tang and Miller, 1991). This study showed a significant decrease in rice-grain yield as the soil As content increased. The toxicity of As is usually manifested as the "straighthead disease" as observed in the USA (Meharg and Hartley-Whitaker, 2002). 
Table 3: Correlation between the amount of applied roxarsone and the arsenic concentrations in soil and various plant parts of rice.

\begin{tabular}{|c|c|c|c|c|c|c|c|}
\hline & Roxarsone & Soil total As & Root inorg. As & Straw inorg. As & Leaf inorg. As & Husk inorg. As & Grain inorg. As \\
\hline Roxarsone & 1 & $0.99^{*}$ & 0.96 & 0.92 & 0.91 & 0.87 & 0.98 \\
\hline Soil total As & & 1 & 0.96 & 0.97 & 0.90 & 0.87 & 0.98 \\
\hline Root inorg. As & & & 1 & 0.95 & 0.82 & 0.75 & 0.93 \\
\hline Straw inorg. As & & & & 1 & 0.82 & 0.85 & 0.94 \\
\hline Leaf inorg. As & & & & & 1 & 0.86 & 0.87 \\
\hline Husk inorg. As & & & & & & 1 & 0.87 \\
\hline Grain inorg. As & & & & & & & 1 \\
\hline
\end{tabular}

${ }^{*}$ All correlation values with $p<1 \%$

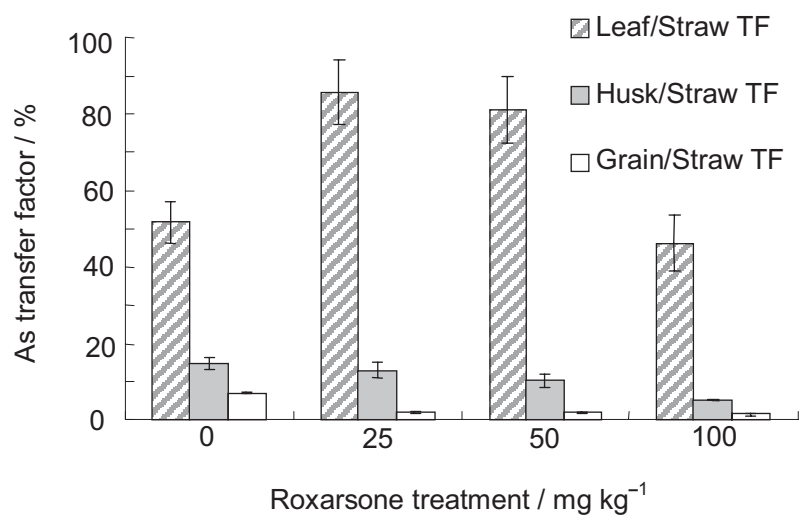

Figure 4: Arsenic transfer factors (TF) between various plant parts of rice. Means \pm SE of three replicates.

\subsection{Arsenic in different parts of rice plants}

The results show that total As in rice plant parts significantly increased with soil As content. The As concentrations in different plant tissues in all treatments followed the order: root $>$ straw $>$ leaf $>$ husk $>$ grain. Arsenic reportedly accumulated more in roots than in aboveground plant parts (Chaturvedi, 2006). Also in our study, the root stored the largest amount of As. However, As may be adsorbed in large amounts by the iron plaque on the root surface (Liu et al., 2006), but iron plaque was not analyzed in our study.

The As speciation indicated that arsenite is the dominant species in root, straw, and grain, while arsenate is the dominant species in leaf and husk. However, this work does not detect the presence of MMA and DMA. A possible reason may be the reportedly low uptake of organic As compared to that of inorganic As species (Odanaka et al., 1987). Particularly DMA and MMA are taken up by rice roots at a slow rate (Abedin et al., 2002c). On average, ratios of inorganic As to organic As in soil solution are 93 to 7 and the ratios of arsenite to arsenate are 60 to 33 .

Several factors affect the As speciation in a plant. Arsenite is the dominant species in submerged soils (Marin et al., 1993). Arsenate and arsenite are the inorganic and phytoavailable forms of As in soil, being available to rice and following the order: DMA $<\mathrm{As}(\mathrm{V})<\mathrm{MMA}<\mathrm{As}(\mathrm{III})$ (Marin et al., 1992). Plants take up arsenate, the predominant form of As in aerobic soils, through phosphate transporters (Meharg and Hartley-Whitaker, 2002). However, because paddy soils are flooded during the rice-growing season, arsenite becomes the predominant chemical species of As and is absorbed via aquaporins into the rice root (Meharg and Rahman, 2003).

In the reduced environment of a flooded soil (Marin et al., 1993), As is present predominantly in the inorganic form with arsenite concentrations exceeding those of arsenate. Thus, arsenite is the dominant species in root and straw of rice. Additionally in this work, the arsenite exceeded arsenate concentrations in straw, but the arsenate exceeded the arsenite in leaf and husk, indicating a possible oxidation of arsenite in the plants as suggested by Schmidt et al. (2004).

\subsection{Potential health hazards of arsenic in rice grain and straw}

The shoots and grains of rice grown in As-contaminated soil can accumulate high levels of As (Abedin et al., 2002a, b). Therefore, the uptake of As by rice plants plays an important role in the transfer of this toxic element into food chains, resulting in potential threats to human health (Meharg and Rahman, 2003). This study indicates that the total As and inorganic As concentrations in rice grains are $1.14 \mathrm{mg} \mathrm{kg}^{-1}$ and $0.89 \mathrm{mg} \mathrm{kg}^{-1}$ after application of $100 \mathrm{mg}$ roxarsone ( $\mathrm{kg}$ soil) $)^{-1}$. The total As concentration in rice exceeded the statutory limit of $1.0 \mathrm{mg} \mathrm{As} \mathrm{(kg} \mathrm{dry} \mathrm{weight)}{ }^{-1}$ in rice grain in Australia (National Food Authority, 1993) and the inorganic As exceeded the limit of $0.15 \mathrm{mg} \mathrm{kg}^{-1}$ in China (GB2762-2005 China National Standard).

The assessment of health risks due to As in rice has largely been based on the inorganic-As concentration because inorganic species are considered to be more toxic than the organic As. Also in our research, inorganic As makes up nearly $80 \%$ of the total As in grain, which is similar to the $86 \%$ reported by Schoof et al. (1998). Assuming an average inorganic-As content of $75 \%$ of the total As, rice grain with $1 \mathrm{mg} \mathrm{kg}^{-1}$ of total As contains $0.75 \mathrm{mg} \mathrm{kg}^{-1}$ of inorganic As, which exceeds by far the health standard of China $\left(0.15 \mathrm{mg} \mathrm{kg}^{-1}\right)$. Additionally, this work shows that the As concentration in rice straw may reach $60 \mathrm{mg}$ ( $\mathrm{kg}$ dry weight) ${ }^{-1}$ 
with arsenite being the predominant As species. Rice straw is widely used as cattle feed (Abedin et al., 2002a), and feeding As-contaminated straw to cattle may result in elevated As contents in meat and milk. Thus, a high As concentration in the straw may not only pose a direct threat to animal health but also an indirect threat to human health.

\section{Conclusion}

The study reveals that roxarsone added to paddy fields is transformed predominantly into arsenite and to a lesser extent to arsenate. Di- and mono-methylarsinic acid only occur in trace levels. The average As contents in grain in this study exceeded the statutory limits for both total and inorganic As in plants. We conclude that high application rates of roxarsone to rice fields result in As toxicity in rice and potentially threaten human health via food chain exposure.

\section{Acknowledgments}

The authors thank the National Science Council of the Republic of China, for financially supporting this research under Contract No. NSC 96-2628-B-002-021-MY3.

\section{References}

Abedin, M. J., Cotyter-Howells, J., Meharg, A. A. (2002a): Arsenic uptake and accumulation in rice ( Oryza sativa L.) irrigated with contaminated water. Plant Soil 240, 311-319.

Abedin, M. J., Cresser, M. S., Meharg, A. A., Feldmann, J., CotterHowells, J. (2002b): Arsenic accumulation and metabolism in rice (Oryza sativa L.). Environ. Sci. Technol. 36, 962-968.

Abedin, M. J., Feldmann, J., Meharg, A. A. (2002c): Uptake kinetics of arsenic species in rice plants. Plant Physiol. 128, 1120-1128.

Brown, B. L., Slaughter, A. D., Schreiber, M. (2005): Controls on roxarsone transport in agricultural watersheds. Applied Geochemistry 20, 123-133.

Chaturvedi, I. (2006): Effect of arsenic concentration on growth and arsenic uptake and accumulation by rice (Oryza Sativa) genotypes. Electron. J. Environ. Agric. Food Chem. 5, 1546-1552.

Edwards, D. R., Daniel, T. C., Marbun, O. (1992): Determination of best timing for poultry waste disposal: A model approach. Water Resour. Bull. 28, 487-494.

Hancock, T. C., Denver, J. M., Riedel, G. F., Miller, C. V. (2002): Source, transport, and fate of arsenic in the Pocomoke River Basin, a poultry dominated Chesapeake Bay Watershed, in: Proceedings of Arsenic in the Environment Workshop, February 21-22, 2001. U.S. Geological Survey, Denver, Colorado.

Huang, Y. K., Lin, K. H., Chen, H. W., Chang, C. C., Liu, C. W., Yang, M. H., Hsueh, Y. M. (2003): Arsenic species contents at aquacultural farm and in farmed mouthbreeder (Oreochromis Mossambicus) in blackfoot disease hyperendemic areas. Food Chem. Toxicol. 41, 1491-1500.

Hyer, K., Hornberger, G., Herman, J. (2001): Processes controlling the episodic streamwater transport of atrazine and other agrichemicals in an agricultural watershed. J. Hydrol. 254, 47-66.
Jackson, B. P., Bertsch, P. M. (2001): Determination of arsenic speciation in poultry wastes by IC-ICP-MS. Environ. Sci. Technol. $35,4868-4873$.

Jackson, B. P., Miller, W. P. (1999): Soluble arsenic and selenium species in fly ash/organic waste-amended soils using ion chromatography-inductively coupled plasma spectrometry. Environ. Sci. Technol. 33, 270-275.

Krishnamurti, G. S. R., Naidu, R. (2002): Solid-solution speciation and phytoavailability of copper and zinc in soils. Environ. Sci. Technol. 36, 2645-2651.

Liu, W. J., Zhu, Y. G., Hu, Y., Williams, P. N., Gault, A. G., Meharg, A. A., Charnock, J. M., Smith, F. A. (2006): Arsenic sequestration in iron plaque, its accumulation and speciation in mature rice plants (Oryza sativa L.). Environ. Sci. Technol. 40, 5730-5736.

Marin, A. R., Masscheleyn, P. H., Patrick Jr., W. H. (1992): The influence of chemical form and concentration of arsenic on rice growth and tissue arsenic concentration. Plant Soil 139, 175-183.

Marin, A. R., Masscheleyn, P. H., Patrick Jr., W. H. (1993): Effect of dimethylarsenic acid (DMAA) on growth, tissue arsenic, and photosynthesis of rice plants. J. Plant Nutr. 16, 865-880.

Meharg, A. A., Hartley-Whitaker, J. (2002): Arsenic uptake and metabolism in arsenic resistant and nonresistant plant species. New Phytol. 154, 29-43.

Meharg, A. A., Rahman, M. D. M. (2003): Arsenic contamination of Bangladesh paddy field soils: implications for rice contribution to arsenic consumption. Environ. Sci. Technol. 37, 229-234.

Mellon, M., Benbrook, C., Benbrook, K. L. (2001): Hogging It: Estimates of Antimicrobial Abuse in Livestock. Union of Concerned Scientists Publications, Cambridge, Mass.

Moore, P. A, Daniel, T. C., Gilmour, J. T. (1998): Decreasing metal run off from poultry litter with aluminum sulfate. J. Environ. Qual. 27, 92-99.

National Food Authority (1993): Australian Food Standard Code. Australian Government Public Service, Canberra, Australia.

Odanaka, Y., Tsuchiya, N., Matano, O., Goto, S. (1987): Absorption, translocation and metabolism of the arsenical fungicides, iron methanearsonate and ammonium iron methanearsonate in rice plants. J. Pesticide Sci. 12, 199-208.

Page, A. L., Miller, R. H., Keeney, D. R. (1982): Methods of Soil Analysis, Part 2, Chemical and Microbiological Properties. 2nd edn., SSSA, Madison, WI.

Rutherford, D. W., Bednar, A. J., Garbarino, J. R., Needham, R., Staver, K. W., Wershaw, R. L. (2003): Environmental fate of roxarsone in poultry litter. Part II. Mobility of arsenic in soils amended with poultry litter. Environ. Sci. Technol. 37, 1515-1520.

Schmidt, A. C., Mattusch, J., Reisser, W., Wennrich, R. (2004): Uptake and accumulation behaviour of angiosperms irrigated with solutions of different arsenic species. Chemosphere 56, 305-313.

Schoof, R. A., Yost, L. J., Crecelius, E., Irgolic, K., Goessler, W., Guo, H.-R., Greene, H. (1998): Dietary arsenic intake in Taiwanese districts with elevated arsenic in drinking water. Hum. Ecol. Risk Assess. 4, 117-135.

Tang, T., Miller, D. M. (1991): Growth and tissue composition of rice grown in soil treated with inorganic copper, nickel, and arsenic. Commun. Soil Sci. Plant Anal. 22, 2037-2045.

Wang, F. M., Chen, Z. L., Zhang, L., Gao, Y. L., Sun, Y. X. (2006): Arsenic uptake and accumulation in rice (Oryza sativa L.) at different growth stages following soil incorporation of roxarsone and arsanilic acid. Plant Soil 285, 359-367. 